\title{
Crustal architecture of the oblique-slip conjugate margins of George V Land and southeast Australia
}

\author{
H. M. J. Stagg $^{1}$ and A. M. Reading ${ }^{2}$ \\ ${ }^{1}$ Geoscience Australia, GPO Box 378, Canberra ACT 2601, Australia (howard.stagg@ga.gov.au) \\ ${ }^{2}$ School of Earth Sciences, University of Tasmania, Private Bag 79, Hobart TAS 7001, Australia (anya.reading@utas.edu.au)
}

Abstract A conceptual, lithospheric-scale cross-section of the conjugate, oblique-slip margins of George V Land, East Antarctica, and southeast Australia (Otway Basin) has been constructed based on the integration of seismic and sample data. This cross-section is characterised by asymmetry in width and thickness, and depth-dependent crustal extension at breakup in the latest Maastrichtian. The broad Antarctic margin ( $\sim 360 \mathrm{~km}$ apparent rift width) developed on thick crust $(\sim 42 \mathrm{~km})$ of the Antarctic craton, whereas the narrow Otway margin $(\sim 220 \mathrm{~km})$ developed on the thinner crust $(\sim 31 \mathrm{~km})$ of the Ross-Delamerian Orogen. The shallow basement (velocities $\left.\sim 5.5 \mathrm{~km} . \mathrm{s}^{-1}\right)$ and the deep continental crust (velocities $>6.4 \mathrm{~km} \cdot \mathrm{s}^{-1}$ ) appear to be largely absent across the central rift, while the mid-crustal, probably granitic layer (velocities $\sim 6 \mathrm{~km} . \mathrm{s}^{-1}$ ) is preserved. Comparison with published numerical models suggests that the shallow basement and deep crust may have been removed by simple shear, whereas the mid-crust has been ductilely deformed.

Citation: H.M.J. Stagg and A.M. Reading (2007), Crustal architecture of the oblique-slip conjugate margins of George V Land and southeast Australia, in Antarctica: A Keystone in a Changing World - Online Proceedings of the $10^{\text {th }}$ ISAES, edited by A.K. Cooper and C.R. Raymond et al., USGS Open-File Report 2007-1047, 109, 6 p., doi: 10.3133/of2007-1047.srp109.

\section{Introduction}

The magma-poor, conjugate continental margins of George V Land (East Antarctica) and the Otway Basin of southeast Australia formed predominantly in an obliqueslip tectonic setting as Australia separated from Antarctica in the Late Cretaceous and Cainozoic (Figure 1). Integration of key interpreted seismic profiles and velocity information from both margins with dredge samples from the deep-water part of the Antarctic margin enables the construction of a crustal profile across the margins in the vicinity of the Spencer Fracture Zone at the time of breakup.

Reconstruction of the continents at breakup in the latest Maastrichtian (Lavin, 1997) is geometrically wellconstrained by the sharp change from the east-west trending, normally-rifted margin between the Great Australian Bight and Terre Adélie / Wilkes Land to the west, to the NNW-SSE trending, oblique- and strike-slip margin between Tasmania and George $\mathrm{V}$ Land to the southeast (see, for example, the reconstruction of Whittaker et al., 2007). This change in trend occurs at the Spencer Fracture Zone, the most westerly of the set of large-offset, dextral fracture zones that span the width of the ocean between southeast Australia and Antarctica (Figure 1). We are therefore confident that the seismic profiles used here (locations in Figure 1) provide a reasonable representation of the structure of the conjugate margins at breakup time. The reconstructed profile extends from the relatively undeformed Palaeoproterozoic crust of the Gawler-Terre Adélie Craton on the Antarctic margin to the Palaeozoic Delamerian-Ross Orogen on the Australian margin (see, for example, Fitzsimons, 2000).

The seismic profiles were acquired by the Institut Français du Pétrole (France; Wannesson et al., 1985) and Geoscience Australia (Stagg et al., 2005) on the Antarctic margin and by Geoscience Australia on the conjugate margin of the Otway Basin (Moore et al., 2000). The

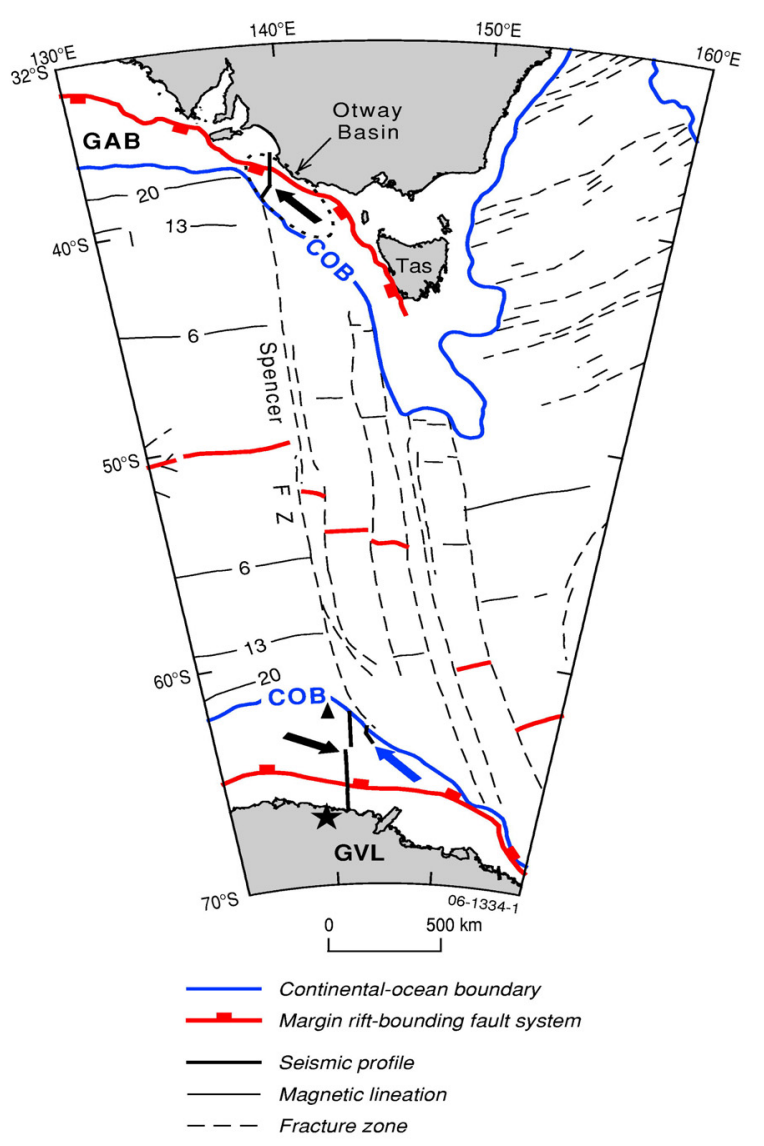

Figure 1. Study area, showing the location of the transect (Figure 2; black arrows) and a detailed seismic profile (Figure 3; blue arrow). The black star shows the location of Dumont d'Urville station. Black triangle on the Antarctic margin shows the location of the dredge samples referred to in the text. $\mathrm{COB}$ - continent-ocean boundary; GAB - Great Australian Bight; GVL George V Land. 
seismic data are generally of high-quality and often show clear reflections down to the base of thecrust. Dredge samples of basement rocks that were recovered by Japan (Tanahashi et al, 1997; Yuasa et al., 1997) from seafloor highs approximately $30-90 \mathrm{~km}$ along-strike to the northwest (Figure 1) have structurally analogous locations on the seismic transect illustrated here (Figure 2) and are a valuable complement to the seismic interpretation.

\section{Interpretation of reflection seismic profiles}

The conjugate seismic reflection profiles are illustrated in Figure 2, and a detailed example from the deep water part of the Antarctic margin is illustrated in Figure 3 to show the seismic character and velocity structure (from non-reversed sonobuoys; Stagg et al., 2005) of the crust near the axis of breakup. The sonobuoys were interpreted by firstly digitising the deep crustal reflectors (down to Moho) and then iteratively ray tracing both refractions and wide-angle reflections to get a best fit with the sonobuoy records. The velocities interpreted in this way can be considered to be reliable.

Oceanic crust has not been included in Figure 2 and the profiles are joined at the interpreted continent-ocean boundary (COB). Where profiles on the Antarctic margin do not intersect, they have been joined at the point of best fit of the seismic sequences. A short segment has been filled by shallow-penetration data; however, the crustal reflectors on each side of the segment can be readily correlated across this segment.

The immediately obvious difference between the margins is the extremely thick post-rift sedimentary section on the Antarctic margin ( $c$ a. $5 \mathrm{~km}$ beneath the continental slope) compared to a few hundred metres of equivalent section on the Australian margin which has been largely sediment-starved since breakup.

In the underlying sedimentary section and crust, the most obvious contrasts between the margins are in the width of the rift from rift-bounding faults to the $\mathrm{COB}$, the thickness of the rift-stage sedimentary section, and in the geometry and seismic character of the crystalline crust. While the landward rift-bounding faults on the Antarctic margin are poorly imaged through the strong multiples, comparisons with other data from the East Antarctic margin, and previous interpretations (e.g. Wannesson, 1990) suggest that the main faults are probably located close to the shelf edge. This gives an apparent rift width of at least $360 \mathrm{~km}$ on this margin. On the Otway Basin margin, unequivocal rift-bounding faults are located beneath the continental shelf and immediately inboard of the shelf break (Figure 2), giving an apparent rift width of about $220 \mathrm{~km}$ and pointing to a high degree of asymmetry across the rift at the time of breakup. Although the lines on both margins are oblique to the primary structural trends $(\mathrm{COB}$, rift-bounding faults and Spencer Fracture Zone), it is obvious that here was a high degree of asymmetry across the rift at the time of breakup.

There is also marked asymmetry in the development of the rift basins underlying the continental slope. The well-stratified sedimentary section in the Otway Basin is up to $8 \mathrm{~km}$ thick and is cut by large numbers of highangle faults (Moore et al., 2000). In contrast, the equivalent section on the Antarctic margin is relatively poorly stratified, cut by fewer faults and no more than about $4 \mathrm{~km}$ thick.

The margin asymmetry is also apparent in the crustal structure of the two margins. On the Otway Basin margin, the main crustal layers are generally quite highly reflective, particularly in the deep crust and inboard of the rift basin depocentre. An Otway margin velocity model approximately $140 \mathrm{~km}$ to the east of the location of the profile in Figure 2 was interpreted by Finlayson et al. (1998) to contain representative velocities for all the major crustal layers beneath the continental shelf $-v i z$. $5.5-5.7 \mathrm{~km} . \mathrm{s}^{-1}$ (their 'upper basement'); $6.15-6.35 \mathrm{~km} . \mathrm{s}^{-1}$ ('deep basement'); 6.4-6.8 km.s ${ }^{-1}$ ('lower crust'), and 6.9-7.8 km.s ${ }^{-1}$ ('upper mantle transition'). Beneath the continental slope, they showed that basin subsidence was mainly controlled by thinning of the 6.15-6.35 and 6.4$6.8 \mathrm{~km} . \mathrm{s}^{-1}$ layers to about $20 \%$ of their onshore thickness. However, the crustal geometry and velocities at long offsets offshore were not well constrained in this dataset (Finlayson et al., 1998). We therefore believe that the Moore et al. (2000) interpretation of the high-quality, deep-penetration, reflection seismic data provide a more accurate indication of the geometry of the crust beneath the continental slope and rise. That interpretation suggested that the accommodation space for the main slope depocentre was provided by removal of most of the seismically-laminated lower crust, while the overlying transparent crust was largely preserved, albeit with pinchand-swell structures suggesting ductile flow at that level. Although Moore et al. (2000) did not suggest a mechanism for the removal of the lower crust, the interpreted seismic profiles implied that the cause was most likely to be simple shear.

Finlayson et al. (1998) interpreted Moho to be at $13 \mathrm{~km}$ depth close to the $\mathrm{COB}$, deepening to $\sim 15-20 \mathrm{~km}$ below the main depocentre of the Otway Basin, and to $\sim 31 \mathrm{~km}$ depth landward of the continental margin. Clitheroe et al. (2000) used receiver function data to interpret a somewhat greater crustal thickness of 35$39 \mathrm{~km}$ onshore within the Delamerian Orogeny.

Seismic data from the deep-water Antarctic margin immediately inboard of the COB (Figs $2 \& 3$ ) show that the main crustal layer (velocity approximately $6 \mathrm{~km} \cdot \mathrm{s}^{-1}$ from multiple sonobuoys in Stagg et al., 2005) is seismically quite transparent, approximately $4-5 \mathrm{~km}$ thick, and is often underlain by a strong, continuous seismic Moho that has marked local relief, including faulting, and has undergone major oceanwards uplift of $3-6 \mathrm{~km}$. The seismic velocity suggests that it comprises mid-continental crust, probably of granitic origin, and that much of the lower crust appears to have been removed, to produce local unloading and uplift of the lithospheric mantle. A crustal velocity of $6.4 \mathrm{~km} \cdot \mathrm{s}^{-1}$ outboard of the 
uplift (Figure 3), together with some scattered velocities in the range of 6.4-6.7 km.s ${ }^{-1}$ (Childs and Stagg, 1987), suggests that isolated fragments of lower crust may have been preserved in this zone of extreme crustal thinning. An approximate depth conversion using representative crustal velocities indicates that Moho lies at about 11$14 \mathrm{~km}$ depth across a broad zone ( $200 \mathrm{~km}$ width) in deep water inboard of the COB, deepening to $18-20+\mathrm{km}$ beneath the continental slope. This is in marked contrast to the Otway margin, beneath which Moho begins deepening only a short distance inboard of the COB.
Rocks dredged from seamount outcrops to the northwest, at an along-strike location on the Antarctic margin from the crust/Moho uplift shown in Figures 2 and 3, included granite, gneiss, slate and diorite (Tanahashi et al., 1997) and peridotite that chemical analysis indicated was a fragment of fertile mantle emplaced at shallow crustal levels during rifting (Yuasa et al., 1997). These dredges support the reflection seismic interpretation that crust of predominantly continental origin extends into abyssal water depths, and that crustal and upper mantle rocks have been locally uplifted and even exhumed at the seabed.

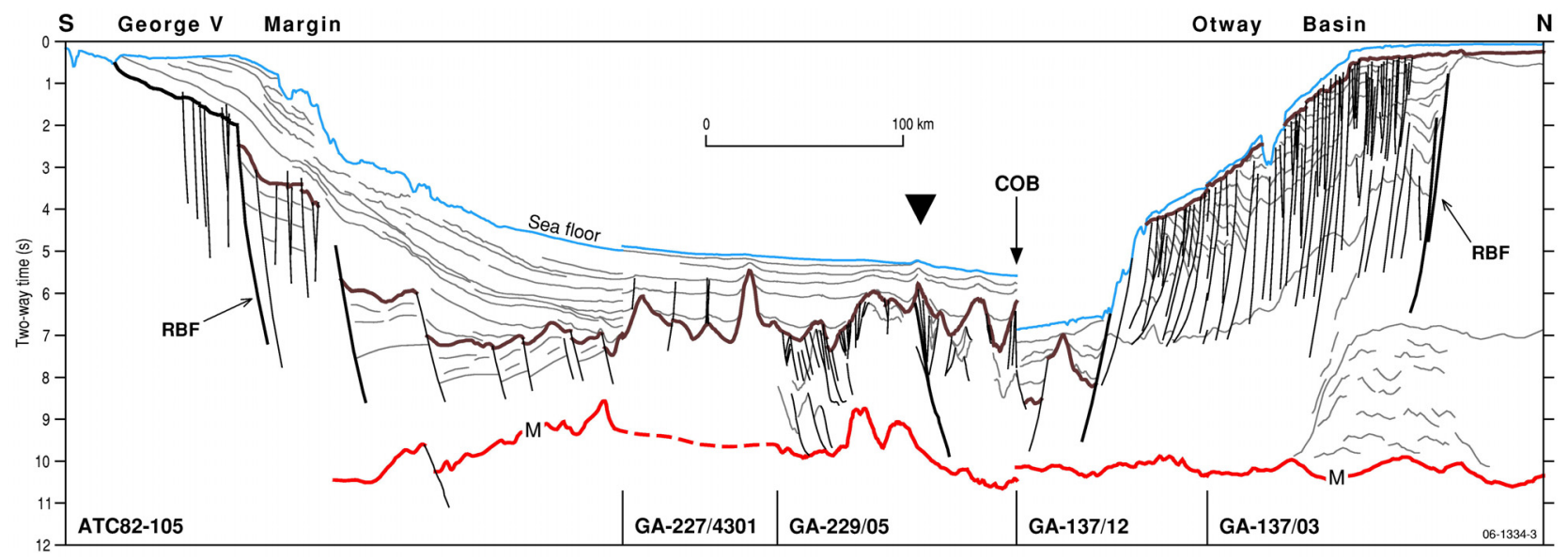

Figure 2. Line drawing of seismic profiles from the George V Land and Otway Basin margins; location in Figure 1. Annotation along base of profile shows actual seismic lines used. Line GA-227/4301 is shallow penetration data. M Moho; COB - continent-ocean boundary; RBF - rift-bounding faults. Triangle shows the structurally analogous location of dredges of Tanahashi et al. (1997) and Yuasa et al. (1997). Brown horizon corresponds to the cessation of margin rifting and approximates the time of margin breakup.

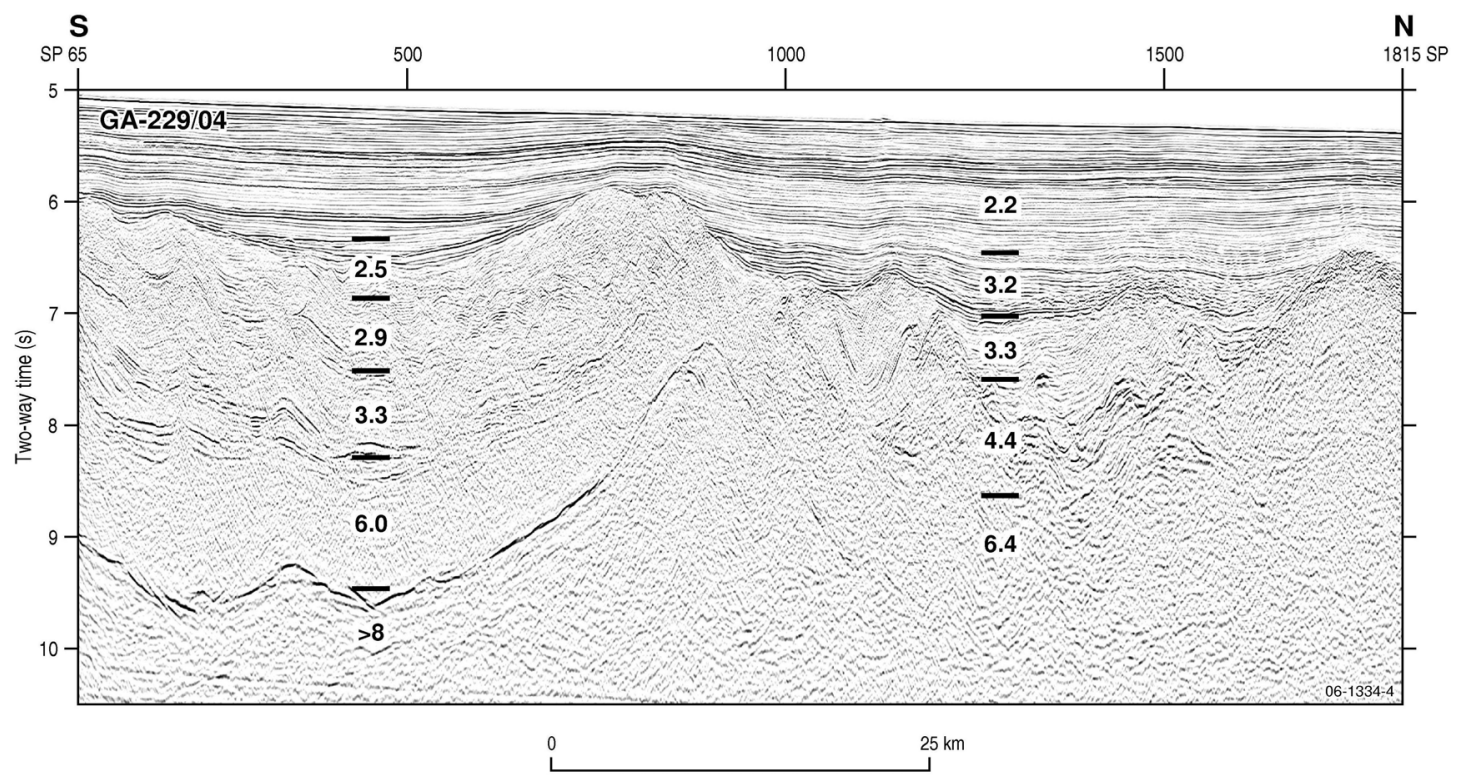

Figure 3. Part of seismic profile GA-229/04 from the George V Land margin, showing the transparent ?granitic crustal layer on the left (8-9.5 s depth) and the underlying, high-relief reflection Moho. Numbers are velocities $\left(\mathrm{km} . \mathrm{s}^{-1}\right)$ from non-reversed sonobuoys. Location shown in Figure 1. 


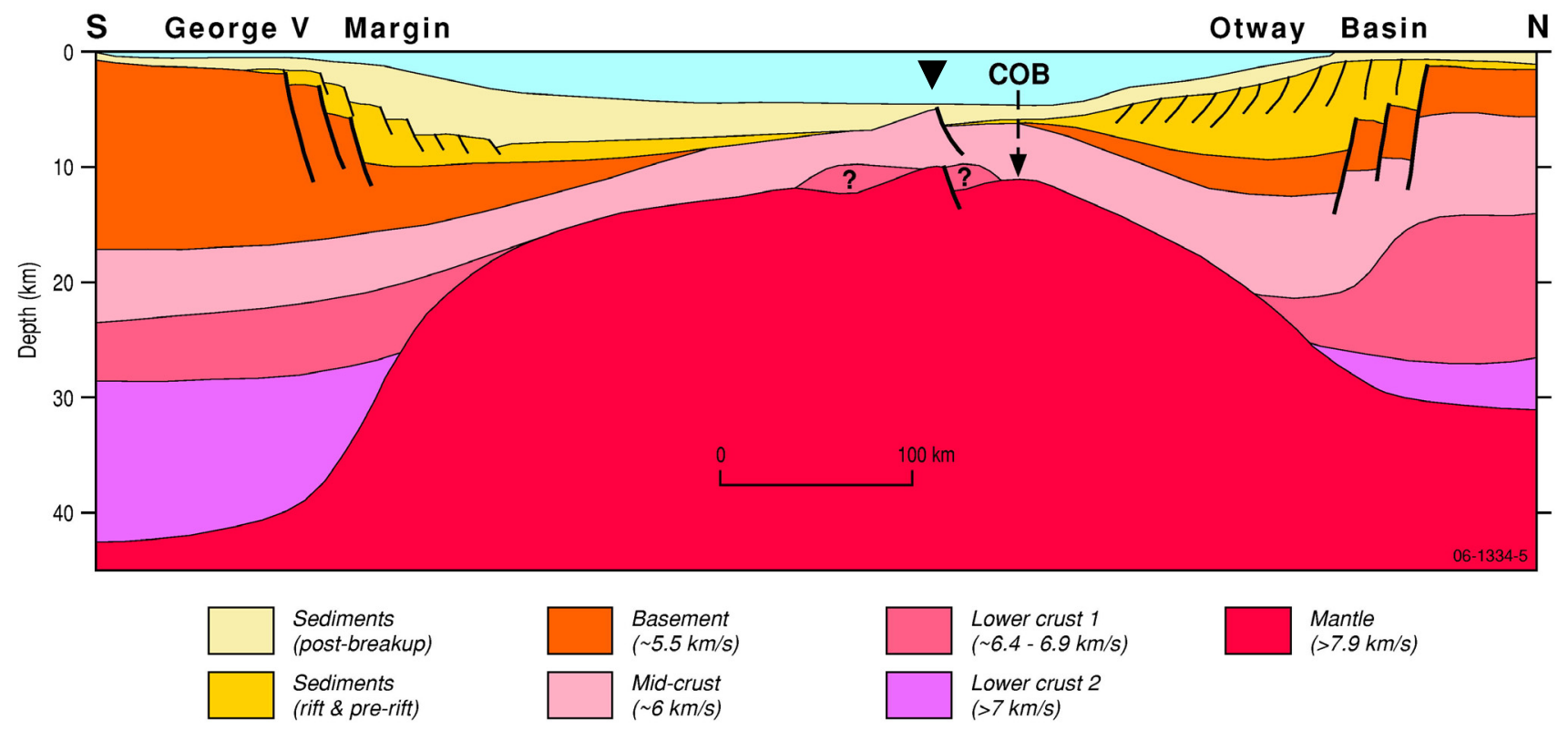

Figure 4. Schematic crustal cross-section across the George V Land and Otway Basin margins, based on seismic and sample data and the interpretation in this paper. $\mathrm{COB}$ - continent-ocean boundary. Triangle shows analogous location of dredges of Tanahashi et al. (1997) and Yuasa et al. (1997) that showed local unroofing of the lower crust and mantle along this margin. Note speculative remnants of lower crust preserved in the central part of the rift.

\section{Schematic conjugate margin depth profile}

Although the seismic profiles in Figure 2 provide an indication of the variation in structure across a conjugate margin pair, the crustal geometries in the time-based seismic data are highly distorted by the approximately 5 -fold velocity increase between the water column and the deep crust. To better represent the crustal structure of the margins of George V Land and the Otway Basin, a schematic depth profile has been constructed to summarise the geometries of the main crustal layers at the time of breakup at the nascent Spencer Fracture Zone (Figure 4). This profile is based on reflection seismic data that have been approximately depth-converted using velocity data from sonobuoys and seismic stacking. The profile also incorporates the localised crustal and mantle unroofing in deep water shown by the dredge samples referred to above.

In the absence of wide-angle seismic data, the crustal structure of the onshore Antarctic end of the profile is adapted from the S-wave velocity model of Reading (2004) at Dumont d'Urville station. This 1-D velocity model was derived from the analysis of teleseismic earthquakes, from which the seismic receiver function was calculated (see Reading [2004] for a discussion of the technique). While this technique does not provide the detail or accuracy available from conventional profile data, there is no other velocity information available in this region. Beneath the onshore Australian end of the profile, we have used the crustal structure interpreted by Finlayson et al. (1998).

The depth profile has not been corrected for the effects of post-breakup thermal subsidence nor for the greater subsidence of the pre-breakup section on the Antarctic margin due to the thick post-rift sediments. In comparing the crustal structures of the two margins, it is important to note that the profile has been coloured only according to the interpreted velocity ranges; caution should be used in extrapolating to actual rock types from these velocities and in correlating the velocity intervals between the margins.

\section{Discussion of depth profile}

There are major differences between the pre-rift velocity structures on the opposing margins. These differences are apparent both in the total crustal thickness (Antarctica $-42 \mathrm{~km}$; Otway margin $-31+\mathrm{km}$ ) and in the relative thicknesses of the different velocity intervals. The differences reflect the different basement provinces (cratonic in Antarctica versus orogenic in Australia) that underpin the margins. In particular, while the midcrustal, probable granitic layer $\left(\sim 6 \mathrm{~km} \cdot \mathrm{s}^{-1}\right)$ is of comparable thickness on both margins, the pre-rift basement $\left(\sim 5.5 \mathrm{~km} . \mathrm{s}^{-1}\right)$ and the deep crustal layers $(\sim 6.4$ $6.9 \mathrm{~km} . \mathrm{s}^{-1}$, and $\left.>7 \mathrm{~km} . \mathrm{s}^{-1}\right)$ are approximately $50 \%$ thicker beneath Antarctica than they are inboard of the Otway Basin. 
The width of the extended part of the margins, as measured from the rift-bounding faults to the $\mathrm{COB}$, is strongly asymmetric $(\sim 360 \mathrm{~km}$ vs $\sim 220 \mathrm{~km})$ at the time of breakup. The asymmetry is most strongly reflected in the width of the continent-ocean transition between the outboard edge of the most highly attenuated continental crust and the COB.

Seismic reflection data and the available sonobuoys (Stagg et al., 2005) suggest that the basement layer with velocities of $\sim 5.5 \mathrm{~km} . \mathrm{s}^{-1}$ may be largely absent across a zone approximately $200 \mathrm{~km}$ wide on the deep-water Antarctic margin, with rift-stage sedimentary rocks directly underlain by seismically transparent mid crust (Figs 2 \& 3). This relationship between rift-stage sedimentary rocks and transparent mid-crust is also observed widely beneath the Wilkes Land margin to the west (e.g. Close et al., 2007). Locally, some shallow basement rocks might be preserved in the central rift, as shown by the dredge samples.

Velocities characteristic of the deep continental crust $\left(>6.4 \mathrm{~km} . \mathrm{s}^{-1}\right)$ are largely absent across a zone $\sim 350 \mathrm{~km}$ in width beneath the central rift, although sonobuoy data (as in Figure 3) suggest that some remanent fragments of this crust may still be preserved in the central part of the rift. As noted by Moore et al. (2000) for the Otway Basin, the interpretation that the high-velocity deep continental crust is not present in this zone finds some support in the seismic reflection character of this crust (Figure 3), which is uniformly transparent to seismic energy, and by the strong and continuous underlying Moho reflection which suggests a strong velocity contrast at this level (Figure 3).

\section{Summary and conclusions}

The schematic depth profile presented here is based on a limited amount of variable quality data and is located in a tectonically complex setting - obliquely astride a nascent oceanic transform near its termination against normally rifted crust. However, despite these complications there are two general features that stand out - viz. the asymmetry between the margins and the depthdependent extension that appears to have left the midcrust still present across the rift while the upper and lower crust may have been totally removed.

Within the range of extant margin formation models, that of Corti et al. (2003) appears to have direct relevance. Those authors used numerical models to show how inherited lithospheric structures influence the process of continental breakup. In particular, they showed that minor perturbations of a few kilometres in depth over a lateral distance of several hundred kilometres in the prerift depth to Moho result in major variations in rift duration, melt production and width and symmetry of the conjugate margin pair. As noted above, the ends of the profile used here are anchored on crust of very different provinces and thickness. These variations are much larger than were shown as significant in the modelling referred to above. It is therefore likely that much of the asymmetry between the margins - in the crust geometries, width of the rift and style and thickness of the rift-stage sediments - can be ascribed to the different extension and subsidence characteristics of the cratonic and orogenic crust.

The issue of the 'missing' shallow basement and deep crust can possibly be explained by the numerical models of Nagle and Buck (2004). This modelling showed that relatively strong lower crust below a ductile mid-crustal layer (equivalent to the transparent mid-crust in Figure 4) can be ruptured during rifting leaving mid-crust directly underlain by mantle. While the George V Land Otway setting is oblique-slip, compared with the normal rifting that was modelled by Nagle and Buck (2004), their model appears to have a strong similarity with the profile developed here, with simple sheared upper and lower crust separated by a mid-crust that has undergone ductile deformation.

Acknowledgements. The authors thank Andrew Krassay, Phil O’Brien, Phil Ball and Morten Sand for their reviews of this paper, and Alan Cooper for his contribution in the review process. The figures were drafted by Silvio Mezzomo. This paper is published with the permission of the Chief Executive Officer, Geoscience Australia.

\section{References}

Childs, J. R., and H. M. J. Stagg (1987), The deep crustal structure of the Wilkes Land continental margin, in The Antarctic continental margin: geology and geophysics of offshore Wilkes Land, edited by S. L. Eittreim \& M. A. Hampton, Earth Science Series, Circum-Pacific Council for Energy \& Resources, 5A, pp 99-115.

Clitheroe, G., O. Gudmundsson, and B. L. N. Kennett (2000), Sedimentary and upper crustal structure of Australia from receiver functions, Australian Journal of Earth Sciences, 47, 209-216.

Close, D. I., H. M. J. Stagg, and P. E. O'Brien (2007), Seismic stratigraphy and sediment distribution on the Wilkes Land and Terre Adélie margins, East Antarctica, Marine Geology, 239 (1-2), 33-57.

Corti, G., J. Van Wijk, M. Bonini, D. Sokoutis, S. Cloetingh, F. Innocenti, and P. Manetti (2003), Transition from continental breakup to punctiform seafloor spreading: how fast, symmetric and magmatic, Geophysical Research Letters, 30 (12), 1604, doi:10.1029/2003GL017374.

Finlayson, D. M., C. D. N. Collins, I. Lukaszyk, and E. C. Chudyk (1998), A transect across Australia's southern margin in the Otway Basin region: crustal architecture and the nature of rifting from wideangle seismic profiling, Tectonophysics, 288, 177-189.

Fitzsimons, I. C. W. (2000), A review of tectonic events in the East Antarctic Shield and their implications for Gondwana and earlier supercontinents, Journal African Earth Science, 31, 3-23.

Lavin, C. J. (1997), The Maastrichtian breakup of the Otway Basin margin - a model developed by integrating seismic interpretation, sequence stratigraphy and thermochronological studies, Exploration Geophysics, 28, 252-259.

Moore, A. M. G., H. M. J. Stagg, and M. S. Norvick (2000), Deep-water Otway Basin: a new assessment of the tectonics and hydrocarbon prospectivity, APPEA Journal, 40 (1), 66-84.

Nagel, T. J., and W. R. Buck (2004), Symmetric alternative to asymmetric rifting models, Geology, 32 (11), 937-940.

Reading, A. M. (2004), The seismic structure of Wilkes Land / Terre Adelie, East Antarctica and comparison with Australia: first steps in reconstructing the deep lithosphere of Gondwana, Gondwana Research, 7 (1), 21-30.

Stagg, H. M. J., J. B. Colwell, N. G. Direen, P. E. O’Brien, B. J. Brown, G. Bernardel, I. Borissova, L. Carson, L., and D. B. Close (2005), Geological framework of the continental margin in the region of the Australian Antarctic Territory, Geoscience Australia Record 2004/25.

Tanahashi, M., T. Ishihara, M. Yuasa, F. Murakami, and A. Nishimura (1997), Preliminary report of the TH95 geological and geophysical survey results in the Ross Sea and the Dumont d'Urville Sea, Proceedings of the NIPR Symposium on Antarctic Geosciences, 10, 36-58. 
Wannesson, J. (1990), Geology and petroleum potential of the Adelie Coast, East Antarctica, in Antarctica as an exploration frontier hydrocarbon potential, geology and hazard, edited by B. St John, AAPG Studies in Geology, 31, pp77-88.

Wannesson, J., M. Pelras, B. Petitperrin, M. Perret, and J. Segoufin (1985), A geophysical transect of the Adélie Margin, East Antarctica, Marine and Petroleum Geology, 2, 192-201.

Whittaker, J. M., R. D. Müller, G. Leitchenkov, H. Stagg, M. Sdrolias, C. Gaina, and A. Goncharov (2007), Major Australian-Antarctic plate reorganization at Hawaii-Emperor bend time, Science, 318, 83-86.

Yuasa, M., K. Niida, T. Ishihara, K. Kisimoto, and F. Murakami (1997), Peridotite dredged from a seamount off Wilkes Land, the Antarctic: emplacement of fertile mantle fragment at early rifting stage between Australia and Antarctica during the final breakup of Gondwanaland, in The Antarctic region: geological evolution and processes, edited by C. A. Ricci, pp 725-730, Terra Antarctica, Sienna. 